\title{
Asynchronous grammaticalization
}

\section{V1-conditionals in present-day English and German}

\author{
Torsten Leuschner and Daan Van den Nest \\ Ghent University
}

The present paper contrasts verb-first (= V1-)conditionals in written usage in present-day English and German. Based on the hypothesis that V1-protases originated in independent interrogatives and then grammaticalized as conditional subordinate clauses in an asynchronous fashion in both languages, we use data from the British National Corpus (BNC) and the Deutsches Referenzkorpus (DeReKo) to investigate the lexical overlap of V1-protases with interrogatives and their functional overlap with 'if-/wenn'-conditionals. The results show, inter alia, that English V1-conditionals are highly divergent from polar interrogatives and occupy a functional niche with respect to 'if-' conditionals, with their German counterparts showing more transitional characteristics in both respects; they also suggest a special role for V1-protases with 'should/sollte' in expressing a subtype of neutral, rather than tentative, conditionality. Finally, prospects are discussed for future research regarding possible synchronic (i.e. discourse-functional) and diachronic (i.e. systemic) motivations for the differences and similarites observed between V1-conditionals in the two present-day languages.

Keywords: conditionals, verb-first, interrogatives, grammaticalization, English/ German

\section{Introduction}

Verb-first (henceforth: V1-)conditionals rarely catch the public limelight, but when the German Chancellor, Angela Merkel, first proclaimed

(1) Scheitert der Euro, scheitert Europa. ${ }^{1}$

fails the Euro fails Europe

"If the Euro fails, Europe fails."

in 2010, she launched a clever (if controversial) slogan which matches a wellestablished constructional and rhetorical pattern in German, cf.

(2) Haste was, biste was.

have.you something are.you something 
"If you have something, you are something."

(3) Kommt Zeit, kommt Rat.

comes time comes advice

"If you allow time to pass, the right advice will suggest itself."

(i.e. "We'll cross that bridge when we get to it.")

(4) Kommst du heute nicht, kommst du morgen.

come you today not come you tomorrow.

"If you don't come today, you can always come tomorrow."

Intentional or not, the association with such comforting pearls of wisdom may explain at least in part the ideological appeal of (1), contributing to the resonance that (1) had as a pro-Euro rallying cry in Germany during the post2008 financial crisis.

Any politician tempted to make a similar move using a V1-conditional in English would be hard put. Searching for English translations of (1) on the internet, one comes across three versions, two of which have 'if' in the protasis, either with the simple present or 'will' in the apodosis, and one has 'should' at the beginning of the protasis and 'will' in the apodosis: ${ }^{2}$

(5) a. If the Euro fails, Europe fails.

b. If the Euro fails, Europe will fail.

c. Should the Euro fail, Europe will fail.

Even (5)c. with clause-initial 'should' in (7) is not a direct replica of (1) for the simple reason that main verbs like 'scheitern' "fail" are excluded from V1protases in present-day English, as indeed is any verb in the present indicative:

(5) d. *Fails the Euro, Europe fails / will fail.

Instead, with a few highly restricted exceptions, English V1-conditionals allow just three verb finite forms in their protasis, viz. 'should', 'had' and 'were' (Quirk et al. 1985:1006, Huddleston and Pullum 2002:753, 970). This was not always the case, as examples like the following show: ${ }^{3}$

(6) Fulga nu se mete ðare wambe willan, \& sio wamb ðas metes, ðonne towyrpð God agger. (YCOE: Cura Pastoralis, late 9th cent.)

"If the food now follow.SUBJ the will of the belly and the belly that of the food, God annihilates both."

(7) Do pu hit eanes awei; ne schalt tu neauer nan oðer swuch acourin.

(PPCME2: Hali Meidhad, c. 1225)

"If you get rid of it once, you will never (re)gain anything like it."

(8) Deceyueth me the foxe / so haue I ylle lerned my casus

(PPCME2: Caxton's History of Reynard the Fox, 1481)

"If the fox deceives me, I have learned my lesson badly."

Since English V1-conditionals clearly used to be more similar to their modern German counterparts in the past than they are today, it is easy to interpret the differences as the result of a fairly recent divergence. This is explicitly proposed 
by König (2012:8f.), who suggests that V1-conditionals in English and German have been developing in an asynchronous fashion: starting out from joint origins in Proto-Germanic times, English V1-conditionals appear to have travelled ahead of their German counterparts along the same grammaticalization path, moving gradually from greater, more German-like variability to the highly restricted state that we find in the data today. ${ }^{4}$

In the present paper, we will review the synchronic (i.e. present-day) evidence for this hypothesis, based on data extracted by Van den Nest (2010a) from the British National Corpus (BNC) and the Deutsches Referenzkorpus (DeReKo). ${ }^{5}$ An important background assumption we make (in line with König 2012, cf. also Hilpert 2010, Auer and Lindström 2012 and others) is that V1protases arose historically from polar interrogatives in a scenario suggested inter alia by Jespersen (1940:374). According to this tradition, V1-conditionals emerged in spoken usage from a 'fictive interaction'-like discourse pattern (Pascual 2014: 35-38) as in (9), which was then reanalysed as a syntactic construction with protasis and apododis:

(9) A: Will you come? (B: Yes.) A: Then we can leave at once.

$>$ Will you come, (then) we can leave at once.

An alternative hypothesis (proposed inter alia by Hopper 1975:50f.) suggests that V1-protases emerged historically from monologual patterns involving V1declaratives rather than interrogatives. While either theory is difficult to prove on philological grounds (Van den Nest 2010a, b), Jespersen's scenario is at least as credible as Hopper's given the interrogative origins of many conditional markers in the languages of the world (Traugott 1985) and the fact that fictiveinteraction patterns like (9) are well-attested in both earlier and present-day German today and even occasionally in earlier English (Van den Nest 2010a):

(10) Heüchelstu nicht mit? so wird man Deiner wenig achten; Heuchelstu aber, vnnd thust auch also? Ach was hertzquelens mustu leiden. (Moscherosch, Gesichte, 1650)

"Do you not play along with the hypocrisy? then you will gain little respect. Do you play along, however, and do as the others? Oh what pains of heart you have to suffer."

(11) Sind Sie neugierig auf die Schalmeien-Musik geworden? Dann lohnt sich ein Besuch am 3. Mai, ab 10.30 Uhr am Krummensee-MannliFest. (DeReKo: A98)

"Have you become curious to hear shawm music? Then a visit to the Krummsensee-Mannli-Festival on May 3rd from 10:30 a.m. is worth your while."

(12) Art thou bound vnto a wife? seeke not to bee loosed. Art thou loosed from a wife? seeke not a wife. (King James Bible; Jespersen 1940:374)

Given the clear structural association of V1-conditionals with polar interrogatives in both German and English, we feel justified in using the presumed interrogative origin of V1-conditionals in English and German as an historical 'tertium comparationis' ${ }^{\prime 6}$ to derive research questions with respect to the present state and, ultimately, the historical development of V1-conditionals. This implies a rejection of any formalist approach that takes the link of V1conditionals with 'if-/wenn'-conditionals as its primary focus and derives V1- 
protases from their 'if-/wenn'-counterparts by V-to-C movement or the like (e.g. Haegeman 2010, Bhatt and Pancheva 2006; cf. Iatridou and Embick 1994 and Haumann 1995 for earlier theories in this vein). Instead, we assume a surfaceoriented position which accounts for the V1-structure through a semantic overlap with (or inheritance from - cf. Kim 2011) interrogatives, based on the fact that both protases and interrogatives signal the non-assignment of truth value to the proposition expressed. As Traugott (1985:293f.) puts it, both set up "alternative possible worlds"- the difference being that the V1-clause has independent illocutionary force in the case of polar interrogatives.

Based on these premisses, we focus our investigation on two grammaticalization parameters from Hopper (1991), viz. divergence and specialization. First, we enquire into the similarity (or otherwise) of V1-protases with polar interrogatives through the phenomenon of lexical overlap: the less lexical overlap there is between the verbs used to introduce V1-protases and polar interrogatives, the more the former will be seen as diverging from the latter. In the first instance, this is a qualitative issue, as we expect to find that German V1-protases can (and indeed do) contain the same finite verbs as polar interrogatives, whereas in English we already suspect V1-conditionals to be introduced only by a well-defined subset (viz. 'should', 'had' and 'were') of the already restricted subset of verbs that can introduce polar interrogatives (viz. all modal and auxiliary verbs). At the same time the issue is a quantitative one, because even if the verbs are the same, various (types of) verbs may still differ in terms of token frequency between the two clause types or the two languages. König (2012:8f.) hints at this possibility: according to his (anecdotal) evidence, German V1-protases show a palpable tendency towards the use of 'sollte', 'hätte' and 'wäre', i.e. precisely the cognates of 'should', 'had' and 'were' in English. If this can be confirmed, it will lend indirect support to the view that V1-conditionals are indeed moving in the same direction in both languages, if more slowly in German than in English.

The criterion of specialization, by contrast, applies to entire conditionals, not just their protases, and requires 'if/wenn'-conditionals as a point of reference, not polar interrogatives. Since conditionals are typically used to signal different degrees of likelihood of the respective states of affairs becoming reality, and therefore display the combinations of tense and mood known called 'realis', 'potentialis' and 'irrealis' (aka 'neutral', 'tentative' and 'counterfactual' conditionality - cf. below), the degree to which V1-conditionals specialize for these functions can be measured by comparing their tense-mood-patterns with those of syndetic conditionals. Again, this criterion (which we call 'functional overlap') is both a qualitative and a quantitative one, and this time we expect English V1-conditionals to display a higher degree of specialization for potentialis and irrealis, i.e. more functional overlap with conditionals, than that displayed (if at all) by their counterparts in German.

In the remainder of this paper, we will proceed as outlined above: by moving from lexical overlap at protasis level, where the point of reference are polar interrogatives (section 2), to functional overlap at the level of the conditional sentence, where the point of reference are 'if-/wenn'-conditionals (section 3), to a brief conclusion (section 4). In doing so, we hope to provide a comparative survey of V1-conditionals in present-day German and English that is useful, not only to descriptive grammar-writing in both languages, ${ }^{7}$ but also to a subsequent comparison of the historical changes that have been affecting V1- 
conditionals in English and German since the beginning of historical documentation ('Sprachwandelvergleich', cf. Fleischer and Simon, eds., 2013).

\section{Lexical overlap}

\subsection{English}

Information in the literature concerning the finite verb forms that occur in V1protases in English is surprisingly sketchy. According to Quirk et al. (1985: 1006), the verbs used are mainly 'had', 'should' and 'were', but 'could' and 'might' are also said to occur (if rarely). Similar information is found in Huddleston and Pullum (2002:753, 970), who claim that 'had' is the verb principally used and that 'should', 'could' and 'dare' also occur occasionally (cf. also Leech 2004:123). Poutsma (1929:706) lists 'had', 'should' and 'were' and also 'did', whereas only 'had', 'should' and 'were' occur according to Sinclair (1996:748), Declerck and Reed (2001:27f.) and Biber et al. (2000:851).

A corpus search in the BNC (100 million words) for the seven verbs listed between these authors proves the last-named group right: all 1,589 V1conditionals attested are introduced by either 'had', 'should' or 'were', never by 'might', 'could', 'dare' or 'did'. Out of the attested three, 'had' $(n=825)$ is by far the most frequent (as claimed by Huddleston and Pullum 2002), followed by 'should' $(\mathrm{n}=584)$ and 'were' $(\mathrm{n}=180)$ :

Figure 1. Verbs in V1-protases in present-day English.

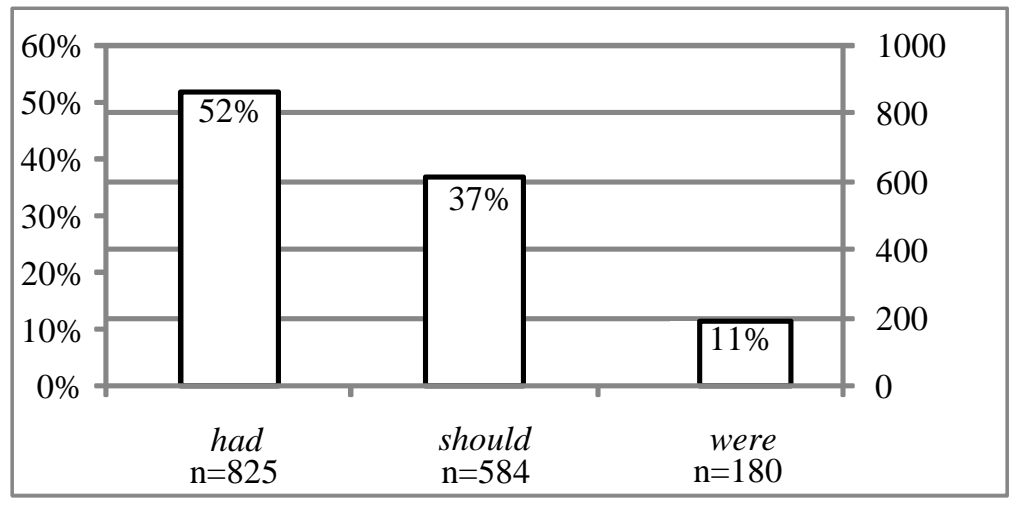

'Had' is almost exclusively used in V1-protases as a pluperfect auxiliary, cf. (13). Only in isolated instances $(n=6)$ does it occur as a main verb, cf. (14):

(13) Had she been alone she would have told him. (BNC: FNU)

(14) Had I access to a neat and sound definition of labourism I would use it; sadly I do not. (BNC: CCR)

The second most frequent verb is 'should':

(15) Should he turn against Major, then the Prime Minister would be finished. (BNC: FBM)

As to were, it almost always represents the 3rd person singular, never the 2nd person, in V1-protases in the BNC. The majority of tokens $(n=98)$ displays the 
idiomatic pattern 'were' + Subjekt + 'to'-infinitive to refer to the future (cf. Quirk et al. 1985:143):

(16) Were his maleness (or Jewishness) to be brought into play, Christ would not be the saviour of all. (BNC: EF0)

On the other hand, 'were' is often used as a copula $(n=55)$, in the set phrase 'were it not for' $(\mathrm{n}=20)$ or as a passive auxiliary $(\mathrm{n}=7)$ :

(17) Were he among familiars it might help him [...]. (BNC: ADS)

(18) Were it not for the tides, it is hard to see how salt marsh could exist at all. (BNC: AMS)

(19) Were $£ 50000$ lent today against repayment of $£ 50000$ in 60 days time this would be the equivalent of the lending institution lending at zero interest. (BNC: K8W)

A comparison with the auxiliaries introducing polar interrogatives in the BNC confirms the highly restricted availability of finite verb forms in English V1protases. The search yields 70,659 tokens in total, with 43 different verb forms ranging from 'is' $(16.79 \%, n=13,676)$ to 'needn't' $(0.001 \%, n=1) .72 \%$ of these forms are in the present tense. Auxiliaries in polar interrogatives may occur with the cliticized negation '-n't', whereas V1-protases allow only the full form 'not' in its normal position behind the subject (Quirk et al. 1985:1094):

(20) Hadn't she cooked for herself and Harriet last Monday? (BNC: CEB).

(20)' *Hadn't / *Had not she cooked for herself and Harriet last Monday, they would have starved.

(20)' Had she not cooked for herself and Harriet last Monday, they would have starved.

Taking in turn the three verb forms which overlap between polar interrogatives and V1-protases (i.e. 'had', 'should' and 'were'), 'had' has a share of just 1.29\% $(\mathrm{n}=1047)$ in polar interrogatives and never occurs as a main verb, only as a pluperfect auxiliary as in (21):

(21) Had you always wanted to be an actor? (BNC: A06)

Functionally, 'had' in polar interrogatives is clearly distinct from 'had' in V1protases. A 'had'-protasis as in (13) - repeated here as (22) - normally expresses that the situation did not occur as described, whereas the corresponding polar interrogative is by default read as a question with an open truth value:

(22) Had she been alone she would have told him. (BNC: FNU)

(22)' Had she been alone?

Analogous differences hold for 'were' and 'should'. 'Should' in conditionals like (23) gets a reading that is clearly distinct from interrogatives like (23)':

(23) Should he turn against Major, then the Prime Minister would be finished.

(23)' Should he turn against Major?

The reading of 'should' in (23)' is deontic and expresses obligation, exactly as in declaratives like (23)', 
(23)'’He should turn against Major.

The element of obligation is lacking in V1-protases; conversely, 'should' in interrogatives never has the same reading as in protases. Huddleston and Pullum (2002) therefore treat 'should' in protases as a separate variant (labeled simply "conditional") which occurs in this type of context only.

The third verb used in polar interrogatives, 'were', occurs (as in V1protases) as a passive auxiliary, as a copula and in the 'were' + subject + 'to' infinitive construction: ${ }^{8}$

(24) Were they watched by the Syrian intelligence service? (BNC: ANU)

(25) Were there other theatre producers you admired at the time? (BNC: $\mathrm{ADP})$

(26) Were you to fend them off or drive them crazy? (BNC: FU7)

Again, there is a clear functional difference: 'were' in interrogatives always expresses a past indicative, as shown when the interrogative is transposed into the 1st or 3rd person singular. The indicative 'was' must then be used:

(24)' Was/*Were I/he watched by the Syrian intelligence service?

We may therefore safely assume that 'were' in (25) and (26) also represents a subjunctive.

These observations support two conclusions. First, although the verb forms attested in V1-protases (viz. 'had', 'should' and 'were') predictably form a proper subset of those that occur in polar interrogatives, the overlap is actually deceptive, as these forms have a distinct meaning in V1-protases from polar interrogatives. Second, it is clear that V1-conditionals cannot be described as emergent from discourse in present-day English the way their counterparts could be described as emergent from discourse in examples like (10) and (11) from German and even (12) from Early Modern English. According to Jespersen's scenario, as sketched above, polar interrogatives may well have been at the historical origin of V1-conditionals, but this association clearly does not hold any longer in English today.

\subsection{German}

In present-day German, the situation is very different: here, the sharp distinction between V1-protases and polar interrogatives that we found in present-day English is lacking, and a broad transition zone between both clause types is unmistakable. A search in the DeReKo's Tagged-TEI-Archiv (20 million words), ${ }^{9}$ which yields a total of 4,259 tokens, fails to suggest any restrictions on the verb types that occur in V1-protases (see figure 2). 
Figure 2. Verb types in V1-protases in present-day German.

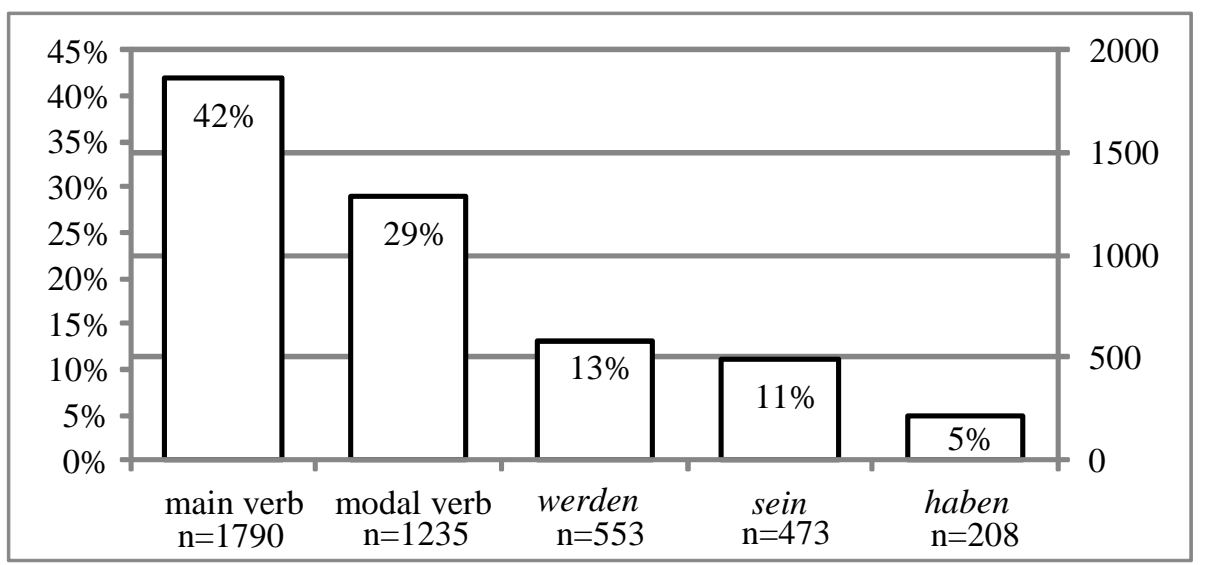

Just under half of all attested V1-protases $(42 \%, \mathrm{n}=1,790)$ are introduced by main verbs. Note the different moods and tenses, as discussed in section 3 below:

(27) Ändern Sie aber das Testament, dann tritt eine neue Rechtslage ein. (DeReKo: MMM)

"If you change the testament, however, a new legal situation arises."

(28) Bräche die Monarchie zusammen, käme die britische Demokratie ohne geschriebene Verfassung nicht aus [...]. (DeReKo: S94)

"Were the monarchy to collapse, British democracy would not be feasible without a written constitution."

(29) Lag die Anlage L den Steuererklärungsvordrucken nicht bei, so fordern Sie sie bitte beim Finanzamt an. (DeReKo: LIM)

"If appendix L was not enclosed with the tax declaration form, please request it from the tax office."

Modal verbs make up $29 \%$ of tokens $(n=1,235)$. This includes forms of 'wollen' ("want"), as in example (28), and also 'können' ("can"), 'müssen' ("must"), 'mögen' ("like, want") and 'dürfen' ("may"), as well as 'sollen' ("must, shall"):

(30) Will man das sportliche Wettkampfprinzip durchaus einführen, so bedarf es unbedingt der verantwortlichen Steuerung durch den Lehrer. (DeReKo: LIM)

"If one really wants to introduce the principle of competition, guidance by a responsible teacher is imperative."

(31) Sollte Wagner tatsächlich im Chefsessel des Bremer Vulkan Platz nehmen, dann kommt eine ungemein schwierige Aufgabe auf ihn zu. (DeReKo: MMM)

"Should Wagner really take up his seat as CEO of Vulkan in Bremen, he is in for an extraordinarily difficult situation."

Just like English 'should', 'sollte' in protases gets a distinct reading, neither deontic nor properly epistemic, in contrast to interrogatives, where it suggests deontic obligation. 
'Werden', too, introduces V1-protases $(13 \%, \mathrm{n}=553)$. As elsewhere in the language, it functions as a main verb 'become' as in (32), as an auxiliary for the passive and the future, and as a paraphrase for the past subjunctive as in (33), yielding the same sense as 'were ... to':

(32) Werden alle Pläne, die das Bonner Forschungsministerium mit Windenergie derzeit hat, Wirklichkeit, dann deckt diese sanfte Energiequelle Ende der 90er Jahre gerade ein Prozent des heutigen Strombedarfs. (DeReKo: MMM)

"If all the plans the Ministry of Research in Bonn has in mind for wind energy at the moment are realized, this environmentally friendly source of energy will cover a mere one percent of present energy needs by the end of the 1990s."

(33) Würde Bundesfinanzminister Theo Waigel (CSU) etwa Umweltsteuern nach schwedischem Vorbild einführen, hätte er 48 Milliarden Mark zusätzlich in der Kasse. (DeReKo: S94)

"Were the federal minster of finances, Theo Waigel (CSU) to introduce, say, an environment tax along Swedish lines, he would have an additional 48 billion deutschmarks in his till."

Like 'werden', 'sein' ("be", $11 \%, \mathrm{n}=473$ ) is attested as a copula verb, as shown in (34), but also as an auxiliary for the perfect or, as in (35), the pluperfect:

(34) Ist 'Dove' erfolgreich, schließt Dieter Meuderscheid, Chef der Unilever-Tochter Lever GmbH, eine Ausweitung der Produktion auch für das europäische Ausland nicht aus. (DeReKo: MMM)

"If 'Dove' is successful, Dieter Meuderscheid, CEO of Unilever's subsidiary Lever $\mathrm{GmbH}$, does not exclude extending production for the remaining countries of Europe."

(35) Wäre alles legal gewesen, hätte damit jeder der co-op-Lenker freiwillig auf einen Gewinn von 50 bis 70 Millionen Mark verzichtet. (DeReKo: S93)

"If all had been legal, every single co-op executive would have voluntarily relinquished a gain of 50 to 70 million deutschmarks."

Finally, some German V1-protases are also introduced by 'haben' ("have”, 5\%, $\mathrm{n}=208$ ). 'Haben' occurs as a main verb expressing possession as in (36), as well as serving as a perfect or pluperfect auxiliary:

(36) Haben zwei Spieler die gleiche niedrigste Karte, so zahlen beide. (DeReKo: LIM)

"If two players have the same card, the lowest, they both pay."

As shown by these examples, German V1-protases allow forms of both past and present, both indicative and subjunctive. The statistical distribution of the four categories, however, is uneven. As Figure 3 shows, the majority of tokens is in the present indicative $(58.2 \%, \mathrm{n}=2,478)$, and the past subjunctive is also common $(38.9 \%, \mathrm{n}=1,658)$. By contrast, the present subjunctive and the past indicative are marginal, together amounting to just $2.9 \%$. 
Figure 3. Tense and mood in V1-protases in present-day German.

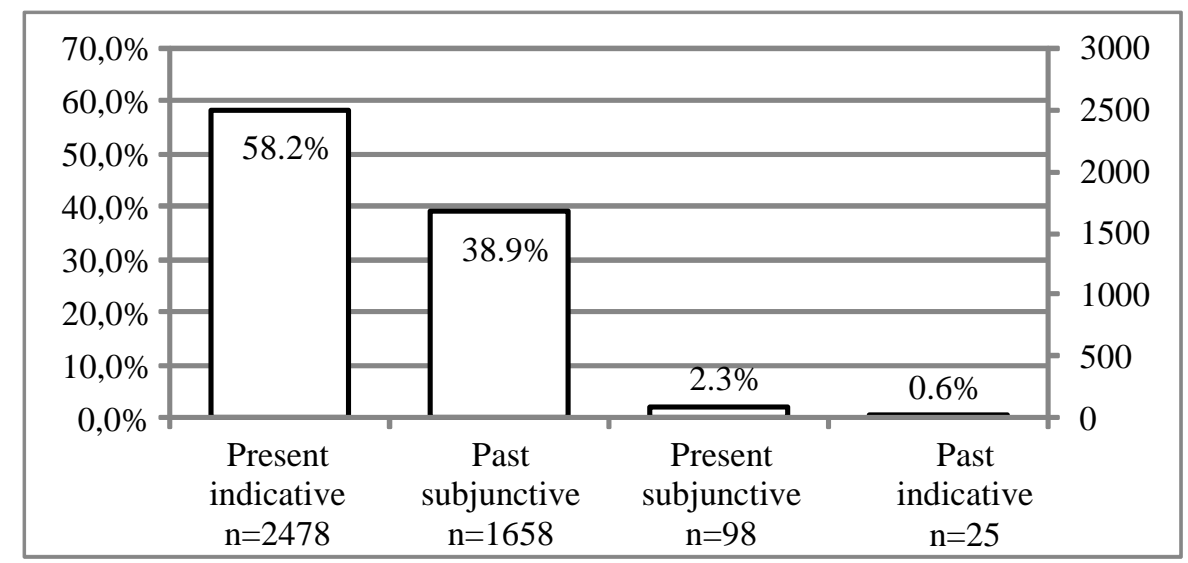

Given the wide range of variability of the verb in German V1-protases, it is not surprising that V1-conditionals are altogether more common in terms of relative text frequency in German than in English. In the German Tagged-TEI-Archiv V1-conditionals amount to $0.2417 \%$ of all sentential units $(4,259$ / 1,762,299) in German, making them almost ten times as frequent as in the English BNC, where they amount to just $0.0255 \%(1,589 / 6,232,360)$ - clearly a significant difference, as shown by Fisher's Exact Test $(p<0.00001)$.

The greater variability of verbs in V1-protases in German also implies a greater similarity with polar interrogatives than in English. A search for polar interrogatives in the Tagged-TEI-Archiv yields 5,990 tokens in total and shows that polar interrogatives are introduced by the same types of verbs as V1protases, viz. main verbs, modal verbs and the auxiliaries 'werden', 'sein' and 'haben'. Polar interrogatives and V1-protases each display the full range of modals available in German, i.e. 'können', 'sollen', 'wollen', 'müssen', 'mögen' and 'dürfen'; 'sein', 'werden' and 'haben' all occur as both main verbs and auxiliaries in each clause type. The same holds for tense and mood: verbs in German polar interrogatives display the same range of variation as in V1protases, occurring in the present and past indicative and in the present (i.e. quotative) and past subjunctives. Example (37) shows the past subjunctive of 'lassen' ("let, allow, enable"):

(37) Ließe sich 'die Angelegenheit' nicht geräuschlos beilegen? (DeReKo: S93)

"Wouldn't it be possible to settle 'the affair' quietly?"

However, the relative share of the categories is different in polar interrogatives, as suggested by Figure 4 . 
Figure 4. Verb types in polar interrogatives in present-day German.

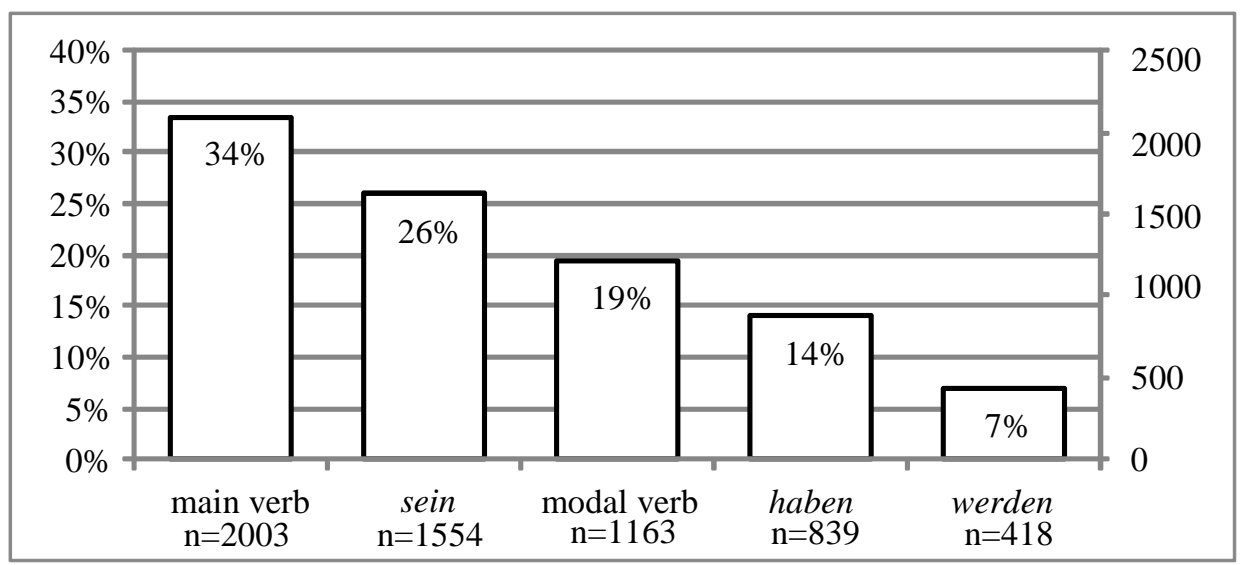

Although main verbs are the most frequent verb type in both polar interrogatives and V1-protases, they are used somewhat less in polar interrogatives (34\%, $\mathrm{n}=2,003$ ) than in V1-protases. Modal verbs amount to almost a third of tokens in V1-protases, but to less than a fifth in polar interrogatives $(19 \%, \mathrm{n}=1,163)$; 'werden' amounts to $13 \%$ of V1-protases, but to just $7 \%$ in polar interrogatives. On the other hand, 'sein' and 'haben', which respectively make up 11\% and 5\% of verbs in V1-protases, are considerably more frequent in polar interrogatives: 'sein' is almost twice as frequent at $26 \%$ of tokens $(n=1,551)$, and 'haben' is three times as frequent $(14 \%, \mathrm{n}=839)$. And as Figure 5 shows, tense and mood also have different relative shares in plora interrogatives than in V1-protases (cf. Figure 3 above).

Figure 5. Tense and mood in polar interrogatives in present-day German.

\begin{tabular}{|c|c|c|c|c|c|}
\hline \multicolumn{5}{|c|}{$90.0 \%$} & \multirow{2}{*}{$\begin{array}{l}6000 \\
5000\end{array}$} \\
\hline $80.0 \%$ & \multirow{8}{*}{$82.1 \%$} & & & & \\
\hline $70.0 \%$ & & & & & \multirow{8}{*}{$\begin{array}{l}4000 \\
3000 \\
2000 \\
1000 \\
0\end{array}$} \\
\hline $60.0 \%$ & & & & & \\
\hline $50.0 \%$ & & & & & \\
\hline $40.0 \%$ & & & & & \\
\hline $30.0 \%$ & & & & & \\
\hline $20.0 \%$ & & $10.6 \%$ & $7.3 \%$ & & \\
\hline $10.0 \%$ & & & & $0.1 \%$ & \\
\hline & $\begin{array}{l}\text { Present } \\
\text { ndicative } \\
n=4906\end{array}$ & 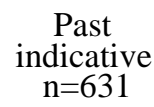 & $\underset{\substack{\text { Pabjunctive } \\
\text { sub435 }}}{\text { Past }}$ & $\begin{array}{c}\text { Present } \\
\text { subjunctive } \\
\mathrm{n}=5\end{array}$ & \\
\hline
\end{tabular}

A comparison of Figures 3 and 5 suggests the following main difference: whereas verbs in V1-protases are predominantly in the present indicative $(58.2 \%)$ or in the past subjunctive $(38.9 \%)$, polar interrogatives are overwhelmingly in the present indicative $(82.1 \%, \mathrm{n}=4,906)$ and occasionally in the past subjunctive $(7.3 \%, \mathrm{n}=435)$. Overall, these differences are highly significant, as shown by the Chi Square test: $\chi^{2}(3)=1231.918 ; p<0.00001$. Also conspicuous is the high incidence of past forms, which is much greater in V1-conditionals than in polar interrogatives. Since German V1-protases are not restricted to the past, forms of the present could in principle be just as frequent 
in V1-protases as in polar interrogatives. In fact, past forms (especially in the subjunctive) are much more common in V1-protases than in polar interrogatives. And since past verb forms are the only ones to occur in V1-protases in English, this makes German V1-protases similar to their English cousins to a certain extent.

A more detailed picture emerges from a comparison between the token frequencies of the verb forms attested in V1-protases in each language. As Table 1 shows, the German cognates of English 'had', 'should' and 'were' (i.e. of precisely those verb forms which occur in V1-protases in English) are among the 15 most frequent verb forms in German V1-protases. The most frequent form is 'sollte' $(\mathrm{n}=703)$; its plural form 'sollten' is the second most frequent $(n=263)$, representing $22 \%$ of all tokens between them. 'Hätte' is the fifth most frequent form $(n=153)$, amounting to $4.6 \%$ of tokens with its plural form 'hätten' ( $\mathrm{n}=43$, in turn the fifteenth most frequent form). 'Wäre' is the seventh most frequent form $(2.4 \%, n=102)$. So although the relative ranking of the forms differs from that of their English cognates, and other verb forms also occur, there is a clear tendency in V1-protases in German to privilege the very forms whose cognates occur in V1-protases in English. König's hypothesis that German V1-conditionals are in fact more similar to their English counterparts in terms of protasis verbs than one might expect at first sight (2012:8f.) is therefore spot-on.

Table 1. The 15 most frequent verbs in V1-protases in German.

\begin{tabular}{|lll|lll|lll|}
\hline \hline Vfin & $\mathrm{n}$ & $\%$ & Vfin & $\mathrm{n}$ & $\%$ & Vfin & $\mathrm{n}$ & $\%$ \\
\hline \hline sollte & 703 & $16,5 \%$ & würde & 120 & $2,8 \%$ & will & 74 & $1,7 \%$ \\
sollten & 263 & $6,2 \%$ & wäre & 102 & $2,4 \%$ & würden & 73 & $1,7 \%$ \\
wird & 242 & $5,7 \%$ & sind & 86 & $2,0 \%$ & kommt & 67 & $1,6 \%$ \\
ist & 229 & $5,4 \%$ & hat & 84 & $2,0 \%$ & geht & 62 & $1,5 \%$ \\
hätte & 153 & $3,6 \%$ & werden & 81 & $1,9 \%$ & hätten & 43 & $1,0 \%$ \\
\hline
\end{tabular}

A final comparison of these frequencies with the corresponding frequencies in polar interrogatives throws these data into extra relief. 'Hätte'* and 'hätten' $* *$ in polar interrogatives amount respectively to just $0.9 \%(n=53)$ and $0.4 \%(n=22)$ of tokens and 'wäre'*** to $1.2 \%(\mathrm{n}=74)$. The differences are highly significant: ${ }^{*} \chi^{2}$ $(1)=92.321, \mathrm{p}<0.0001 ; * * \chi^{2}(1)=16.222, \mathrm{p}<0.0001 ; * * * \chi^{2}(1)=193.695, \mathrm{p}$ $<0.0001$. Although 'sollte' and 'sollten', the most frequent verb forms in German V1-protases, also occur in polar interrogatives (with a distinct, deontic meaning), they are much rarer there: 'sollte' only makes up $1.2 \%(n=72)$ in polar interrogatives and 'sollten' as little as $0.3 \%(n=20)$. 


\section{Functional overlap}

\subsection{Levels of clause-linkage}

As is well-known, conditional (and other adverbial) relationships can be expressed at different levels: content, inferential, and illocutionary (Sweetser 1990, cf. also Dancygier 1998). Most examples cited so far belong to the content level, i.e. they express a causal ('deontic') relationship between two states of affairs, $p$ and $q$, such that $p$ is a sufficient condition for the realization of $q$. Since this relationship enables speakers to make predictions from one state of affairs to another, prototypical content-level conditionals are often called 'predictive' in the literature (Schwenter 1999:15, cf. Dancygier 1998:43ff.). For instance, conditionals (38) and (39) express predictions or speculations as to what happens if the dam is bombed or if Scharping becomes Chancellor:

(38) Should an enemy ever bomb the High Dam, Egypt would be washed into the sea by the very waters which have created it. (BNC: FEM)

(39) Wird Scharping Kanzler, stellt der Koalitionspartner den Außenminister. (DeReKo: S93)

"If Scharping becomes Chancellor, the coalition partner provides the foreign minister."

Default features of content-level conditionals in use are the phenomenon of conditional perfection (a conversational implicature by which $p$ is assumed to be not just a sufficient but a necessary condition for $q$ - or in other words: that if non- $p$, then non- $q$, see Sweetser 1990:115, van der Auwera 1997) and a set of constraints on combinations of tense and mood in the main and subordinate clauses, known as consecutio temporum or sequence-of-tenses, which correlate with different evaluations by the speaker as to the probability of $p$ and $q$ being realized in the real world. There are three prototypical types of evaluation (and hence tense-mood combinations), traditionally referred to as 'realis', 'potentialis' and 'irrealis'; we will refer to them by the English terms 'neutral', 'tentative' and 'counterfactual' (Huddleston and Pullum 2002, inter alia).

The levels of clause-linkage and the associated sequence-of-tense phenomena and probability readings are significant because they show that, despite certain differences in frequency, the various formal types of conditionals are more unified than is sometimes assumed in the literature, especially with regard to German (see e.g. Reis and Wöllstein 2010). Content-level V1conditionals express the three levels of likelihood exactly as syndetic conditionals do. Thus, the (constructed) V1-conditionals in (40)-(42) are by default read such that the speaker ...

(40) A: ... remains neutral as to the probability of $p$ and $q$ being realized:

Kommt Tom mit, geht Anna nach Hause.

(present indicative in both clauses) ${ }^{10}$

"If Tom comes along, Anna goes home."

(41) B: ... treats the realization of $p$ and $q$ as merely a tentative possibility:

Käme Tom mit, ginge Anna nach Hause.

(past subjunctive in both clauses) 
"Were Tom to come along, Anna would go home."

(42) $\mathrm{C}: \ldots$ treats the realization of $p$ and $q$ as a non-possibility (viz. as counterfactual):

Wäre Tom mitgekommen, wäre Anna nach Hause gegangen.

(pluperfect subjunctive in both clauses)

"Had Tom come along, Anna would have gone home."

In contrast to content-level conditionals, inferential conditionals are not used to make predictions; instead, the protasis is treated as a premiss for a logical inference drawn in the apodosis. Such conditionals (aka 'epistemic') are not subject to either conditional perfection or sequence of tenses, i.e. they freely allow any combination of tenses and moods regardless of degrees of likelihood. V1-conditionals at the inferential level are relatively rare, especially in English, but they are attested:

(43) Stellt man die vielen Wiederholer (bis zu 60 Prozent) in Rechnung, dann waren mit bei [sic] den Veranstaltern bisher erst rund 1300 FirstClass-Pauschalisten unterwegs. (DeReKo: S93)

"If one bears in mind the large number of second-time participants (up to 60 precent), a meagre 1,300 have so far travelled with the holiday package operators in first class for the first time."

(44) Your home region may be similiar to that just described [...]. Should that be the case, then you live in the Gypsum Hills. (from Baird and Goble 1994:16)

Finally, V1-conditionals can express linkage at the illocutionary level. The protasis then expresses a condition under which the speech act being carried out by the apodosis can succeed or be relevant (Sweetser 1990). Illocutionary-level linkage is rare in V1-conditionals, but examples do occasionally occur, at least in German:

(45) Willst du meine Meinung hören, ich gehöre wirklich nich[t] zu der Kategorie der Pusher oder Tagträumer. (http://www.wallstreetonline.de/diskussion/760964-241-250/891624-softbank-400kurspotential, 28-04-2010)

"If you want my opinion, I'm really not in the same category as cheats or daydreamers."

(46) Und, bin ich ehrlich, mir fehlt er doch unheimlich. (http://www.fanfiktion.de/u/Amalia, 28-04-2010)

“And, if I'm honest, I do miss him badly."

Even in English, V1-conditionals can be found which appear to express illocutionary linkage:

(47) "Should you be referring to Vaughan, good uncle, I assure you that he is no vexatious matter," Edward said hotly. (BNC: CCD)

An important feature of conditionals with illocutionary linkage is that their apodosis is separately assertible, i.e. that it expresses by default an assertion concerning a state of affairs that holds in the real world (König and van der Auwera 1988:112). This motivates the lack of structural integration of 
conditionals (including V1 conditionals) in verb-second languages like German: whereas sentence-initial subordinate clauses normally fill the forefield of the verb, protases in illocutionary-level conditionals (V1 or otherwise) generally fail to do so. Integration into the forefield would be indicated by the verb immediately following the subordinate clause, and any other material (including the subject) coming after the verb as e.g. in stellt der Koalitionspartner in (39) above, but with illocutionary-level linkage this is normally impossible:

(45)' Willst du meine Meinung hören, *gehöre ich wirklich nicht zu der Kategorie der Pusher oder Tagträumer.

Instead, the subject (ich) as in (45) or some other topical constituent (mir) as in (46) fills the forefield and the protasis remains structurally outside the apodosis.

The observation that V1-conditionals show the tense-mood patterns and levels of interclausal linkage that are typical of conditionals (including lack of clause-integration with illocuationary-level linkage in German) adds a significant dimension to a discussion that has so far been focused on protasis verbs only. As the sequence-of-tense rule affects only conditionals with linkage at the content level, we will be concerned exclusively with this linkage level from now on. We will be distinguishing the tense-mood patterns $\mathrm{A}$ to $\mathrm{C}$ that were illustrated above in examples (40)-(42), and will often be speaking of 'pattern A/B/C verb forms', i.e. of verb forms that are typically associated with one or another of these patterns and hence with one of three probability readings: neutrality, tentativity, counterfactuality.

\subsection{German}

Given what we know about finite verbs in the protases of V1-conditionals in English and German, we can expect significant differences in the realization of tense-mood patterns between the two languages. After all, English V1-protases are only introduced by 'had', 'should' or 'were', suggesting that V1conditionals in English are restricted to patterns B and C and thus form a proper subset of their German counterparts in this regard. And since more than half of V1-protases in the BNC are introduced by 'had', we can expect English V1conditionals to have predominantly, if not exclusively, non-neutrality (mainly counterfactual) readings. German, by contrast, allows any form of any verb in V1-protases, and since the protasis verb is mostly in the present indicative, we can expect most V1-conditionals to have a neutrality reading in German, even though non-neutrality readings should still be relatively frequent.

The data that we will use to test these expectations consist of a random selection of 500 tokens out of the 4,259 V1-conditionals attested in the TaggedTEI-Archiv. Out of these 500, 20 had inferential or illocutionary linkage and were de-selected manually. Out of the remaining 480 tokens, just over half $(52.9 \%, \mathrm{n}=255)$ showed pattern A, i.e. the neutrality pattern. The vast majority of these $(48.1 \%$, of the total, $n=230)$ have the present indicative in both clauses as shown in (48). A small majority has the future tense in the apodosis $(2.1 \%$, $\mathrm{n}=10)$ or the present perfect in the protasis $(1.3 \%, \mathrm{n}=6)$ :

(48) Sagt der Rat ja, beträgt die Erhöhung drei Prozent. (DeReKo: MMM)

"If the Council agrees, the rise amounts to three percent." 
(49) Bricht das Duo auseinander, wird sich vor allem die CSU freuen. (DeReKo: MMM)

"If the duo breaks up, the Christian-Social Union will be especially glad."

(50) Haben sich auf allen Spuren Kolonnen gebildet, so darf die rechte schneller fahren [...]. (DeReKo: MMM)

"If continuous traffic has formed in all lanes, the right-hand lane is allowed to move faster."

All these patterns get a neutrality reading, as does a tiny minority which has the present subjunctive as a quotative marker in one of the clauses or both (1.6\%, $\mathrm{n}=9$ ).

Among the non-neutrality patterns, pattern B is numerically the more important one with $21.9 \%$ of all tokens $(n=105)$. This pattern has two subtypes, depending on whether the protasis refers to the present or the future; the former (which always has a static verb in the protasis) is by default read counterfactually, the latter usually has a tentativity reading. The subtype relating to the present, as shown in (51)-(52), is rare with just $2.3 \%$ of tokens $(n=11)$ :

(51) Hätte ich ein gutes Gefühl, wäre ich ein Betrüger. (DeReKo: S93)

"If I had a positive premonition, I would be a liar."

(52) Stünde das Museum woanders, gäbe es diese mit Bögen verbundenen Sandsteinsäulen nicht. (DeReKo: S93)

"If the museum were located elsewhere, there wouldn't be those sandstone columns connected by arches."

The remainder of pattern $\mathrm{B}$ conditionals relate to the future and amount to $18.3 \%$ of tokens $(n=88)$. Although this type, which has the past subjunctive in both clauses, is attested with main verbs in the protasis - e.g. 'kommen' ("come") in (53) -, the majority have an auxiliary, e.g. 'werden' in the past subjunctive, i.e. 'würden' ("would"):

(53) Kämen nur alle Dreijährigen, die am 1. Juli eines Jahres Geburtstag haben, im Herbst in den Kindergarten, stünde Mannheim mit nunmehr 70 fehlenden Plätzen glänzend da. (DeReKo: MMM)

"If only and all those three-year olds started going to kindergarten this autumn whose birthday is on July 1st this year, Mannheim would be well-off, coming only 70 places short."

(54) Würde ich mir sein Vertrauen psychologisch erklären, so wäre es nicht mehr Anruf an meine Person, auf den ich mich persönlich einlassen könnte. (DeReKo: LIM)

"Were I to explain his confidence psychologically, it would no longer be a call to myself to which I could respond."

More frequent than 'würde', however, are forms of modal verbs, mainly 'sollen' $(n=30)$ as shown in (54), but also 'können' $(n=2)$, 'müssen' $(n=2)$ and 'wollen' $(\mathrm{n}=1)$ :

(55) Sollte sich das Gegenteil erweisen, hätte dies für Klimmt höchst unangenehme Folgen. (DeReKo: S94) 
"Should the contrary turn out to be the case, this would have extremely unpleasant consequences for Klimmt."

Finally, the counterfactual pattern $\mathrm{C}$, with the past subjunctive in both clauses, is marginal in the German data $(4.1 \%, \mathrm{n}=19)$ :

(56) Hätte ich gewußt, daß es die letzte ist, wäre ich gerne gekommen. (DeReKo: S93)

"Had I known it was the last one, I would gladly have attended."

(57) Wäre auch sie hochgegangen, hätte es [...] allen den Rest gegeben. (DeReKo: S94)

"Had she/it exploded, too, it would have spelled the end for them all."

Apart from the three regular patterns, tokens regularly occur that combine verb forms from different regular patterns. By far the most important such pattern combines the past subjunctive of 'sollen' in the protasis with a pattern-A-form in the apodosis (mostly the present indicative). With a total share of $14.4 \%$ $(n=69)$, it is almost twice as frequent as regular 'sollte'-conditionals with the past subjunctive in the apodosis. The apodosis verb is mostly in the present indicative $(n=49)$, in rare cases in the future tense $(n=4)$ :

(58) Sollten die Eheleute in der Frage der Reihenfolge des Doppelnamens keine Einigkeit erzielen, entscheidet das Los. (DeReKo: MMM)

"Should husband and wife not reach a consensus concerning the order of their names in a double surname, the decision will be taken in a random draw."

(59) Sollte dabei alles klar gehen, wird Kinopolis am 2. Oktober den Betrieb in allen zehn Vorführsälen aufnehmen. (DeReKo: MMM)

"Should the procedure go well, Kinopolis will go into business on October 2nd with all ten screens."

The remaining examples with 'sollte' in the protasis have the present subjunctive in the apodosis, which functions as a quotative marker $(n=16)$.

The special status of 'sollte' in German conditionals has often been noted in the literature (see Reis and Wöllstein 2010:135-137), and so has the ability of 'sollte'-protases to combine with either a pattern-A- or a pattern-B-apodosis. With 'wenn'-conditionals, the corresponding structure looks as follows:

(59)' Wenn dabei alles klar gehen sollte, ...

"If the procedure should go well, ..."

According to Leirbukt (1997:79), such mixed 'wenn-sollte'-conditionals express neutrality just like regular pattern-A-conditionals; Engel (2004:148) similarly appears to suggest that they express something in between neutrality and tentativity. However, this is an ad-hoc account for which we fail to find support in the V1-data. Interestingly, the DeReKo corpus contains V1-conditionals as in (59) with two coordinated protases, the first of which has 'sollte' inV1-position and the second has a verb in the present indicative (like the apodosis) with V2order:

(60) Sollte Fuchs verurteilt werden und es passiert nichts mehr, dann bin ich froh. (DeReKo: N99) 
"Should Fuchs be sentenced and nothing else happens, then I'm glad."

Such structures suggest that at least some speakers are able to interpret 'sollte' as a present indicative in line with the second verb and to treat the whole conditional as an expression of neutrality. Leirbukt (1997:79) seems to suggest that 'sollte' has acquired a present-tense reading by reanalysis, implying ambiguity between a present and a past reading which can be activated on a case-to-case basis, but in the light of examples like (59) this appear unlikely. Instead, (60) suggests that 'sollte' has become vague, at least for some speakers, and that it can now be treated by default as a clause-initial conditionality marker regardless of the other verb forms that appear around it - something also implied, if in different terminology, by Reis and Wöllstein (2010:137). We return to this point below.

\subsection{English}

As with German, our results for English are based on a random selection of 500 tokens extracted out of the 1,589 V1-conditionals attested in the BNC. Among the 500 were 63 with inferential or illocutionary linkage, which were manually deselected, leaving 437 conditionals with content-level linkage for analysis.

The first, unsurprising result is that English V1-conditionals have pattern $\mathrm{C}$ in more than half of all tokens $(53.7 \%, \mathrm{n}=242)$. This pattern invariably gets a counterfactual reading, based mostly on the fact that the protasis refers to an unreal state of affairs in the past $(\mathrm{n}=234)$, as in $(61)$, although reference to an unreal state in the present $(\mathrm{n}=8)$ also occurs, as in (62):

(61) [I was stretched full-length upon the bodies, my battered hand resting on the rim of the tub. The soldier looked at my swollen hand and then back at my face. [...] He held his trouser-front with one hand and with the other he reached forward to prod me.] Had he prodded any other part of my anatomy I would not have yelled. [My hand was lacerated, deformed, and bulbous with pus. I screamed.] (BNC: HR7)

(62) Sir: Had today's date been 1 April many readers like myself would have nodded with quiet pleasure at your splendid little follow-up about Thatchergate (4 October). [Now, however, I wonder if the absurd story is true.] (BNC: $\mathrm{A} 2 \mathrm{~W}$ )

Pattern B, amounting to $9.3 \%$ of all tokens $(n=42)$, is illustrated by (63):

(63) Should an enemy ever bomb the High Dam, Egypt would be washed into the sea by the very waters which have created it. (BNC: FEM)

Apart from 'should', V1-conditionals with pattern B may also be introduced by were in the protasis $(12.1 \%, \mathrm{n}=55)$, in which case the apodosis mostly has 'would' (or else 'might', 'could' or 'should', the latter in the sense of 'would'). The protasis may refer to the present or the future, like 'should' in (63). Interestingly, 'were' -conditionals refer to the future $(7.5 \%, n=34)$, in which case the 'were ... to'-construction is typically used, more often than to the present, as illustrated in (64) $(4.6 \%, n=21)$ :

(64) Were the Bowes Museum located in London rather than one of the greener parts of County Durham in the north of Britain it would surely rank alongside the Wallace Collection in prestige and public affection. (BNC: EBW) 
Apart form such cases, which can be unequivocally assigned to either pattern B or $\mathrm{C}$, the English data also contain mixed cases corresponding to those with German 'sollte' (cf. above). One marginal subtype (3.1\%, n=14), invariably with a counterfactual reading, has the pluperfect (a pattern-C-form) in the protasis and a past modal (a pattern-B-form) in the apodosis:

(65) Had Inverclyde had a policy of installing smoke detectors, and had this house been fitted with them, you and I would not be here today talking about this. (BNC: K5M)

Another, more frequent subtype has 'should' in the protasis and a non-pattern-B form in the apodosis. The apodosis mostly contains a modal or main verb in the present or future $(\mathrm{n}=30)$ :

(66) Should the path fail then the system backtracks to the previous decision point and takes a different path. (BNC: HGR)

(67) Should this be proven, it will be a new complication of a conventional disease. (BNC: B76)

This subtype amounts to more than a fifth of all tokens (21.6\%) and is thus two and a half times as frequent as regular combinations of a 'should'-protasis with a pattern-B-apodosis. This is reminiscent of German, where mixed 'sollte'conditionals are almost twice as frequent as regular 'sollte'-conditionals with a pattern B form in the apodosis. The views expressed in the literature on mixed 'if'-conditionals with 'should' in the protasis - cf. the paraphrase in (59)' above - are analogous to those expressed about mixed 'wenn-sollte'-conditionals: one view (Jespersen 1940:334f.) suggests that they express neutrality, i.e. that "we may substitute a simple present for the 'should'-combination" in such cases (ibd.); another view (represented by Leech 2004:119f. and Huddleston and Pullum 2002:188) maintains that they express a degree of likelihood in between neutrality and tentativity, i.e. "slightly greater doubt", as Huddleston and Pullum (ibd.) put it. As in German, the former view is supported by examples in the BNC containing two coordinated protases, the first of which has 'should' and the second (like the apodosis) a verb in the present indicative:

(68) Should the problem persist, or you cannot contact the Area Manager, the Regional Management Centre is the next point of contact for your complaint. (BNC: EE0)

The ease with which at least some speakers seem to apply a present indicative reading to forms so transparently non-present morphologically, as well as general processing considerations, suggest that 'should' and 'sollte' in conditionals are not processed in paradigmatic opposition to the respective present forms 'shall' and 'soll'. Instead, they have become vague and thus liable to be treated by default as clause-initial conditionality markers regardless of the other verb forms that occur in the same construction.

\subsection{Discussion}

Given the existence of mixed 'if-should'- and 'wenn-sollte'-conditionals with neutrality reading, it does not in itself come as a surprise that there are also corresponding V1-conditionals with 'should' and 'sollte'. Nevertheless it is remarkable, particularly in English, as English V1-conditionals otherwise have a strong tendency towards non-neutrality, as shown in Figure 6. 
Figure 6. Probability readings in English V1-conditionals.

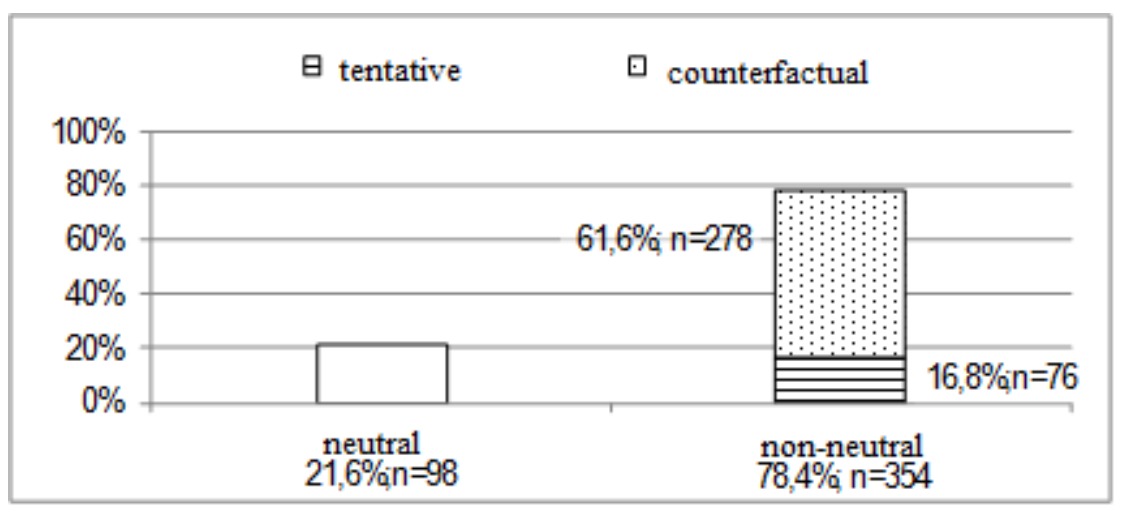

Since the occurrence of neutrality readings in V1-conditionals in English is due exclusively to mixed 'should'-conditionals, these conditionals clearly buck what is otherwise a robust trend. It is as if, thanks to the vagueness of conditional 'should', speakers of English can have their cake and eat it, too - i.e. maintain V1-conditionals as a distinct strategy for the expression of non-neutrality while also using V1-'should' to express neutrality just as in 'if'-conditionals.

In German, the existence and prominence of mixed 'sollte' -conditionals is less remarkable, as suggested by a comparison of Figure 6 with Figure 7.

Figure7. Probability readings in German V1-conditionals.

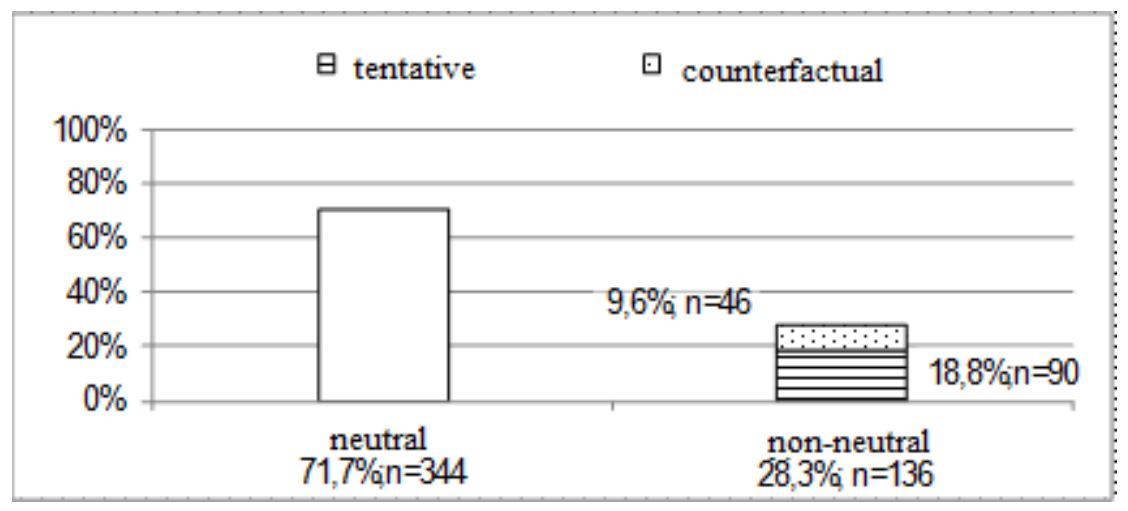

The share of neutrality in German (including mixed 'sollte'-conditionals, $n=69$ ) turns out to be broadly similar to the share of non-neutrality readings in English and vice versa. $28.3 \%$ of tokens in German have non-neutrality readings, with counterfactuals (the largest group in English) being the smallest in German at just $9.6 \%$. Tentativity is in the middle with $18.8 \% \quad(n=90)$, with 'sollte' introducing the protasis in less than half of the tokens $(n=39)$. In other words, despite a palpable tendency for German V1-conditionals to serve non-neutrality functions, this tendency is far less pronounced than in English, hence mixed 'sollte'-conditionals with neutrality readings are also that much less remarkable.

A similar picture is suggested by a comparison with probability readings in 'if-/wenn'-conditionals. In order to investigate English 'if'-conditionals, a random sample of 500 'if'-conditionals from the BNC was taken and manually cleared of inferential and illocutionary tokens (which interestingly amounted to 215, far more than the 63 found in the corresponding sample of 500 V1conditionals). The remaining 285 content-level conditionals were analysed for tense-mood patterns, see Figure 8. 
Figure 8. Probability readings in English 'if'-conditionals.

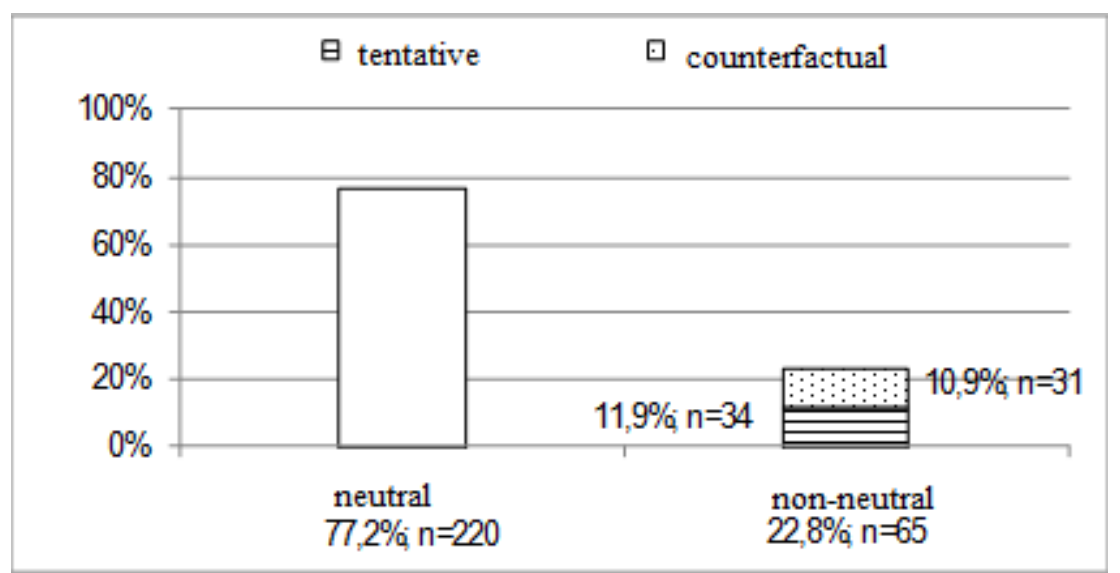

The share of non-neutrality in 'if'-conditionals $(22.8 \%$; $n=65)$ is only about a third of that in V1-conditionals; conversely, neutrality is about three times as frequent in 'if'-conditionals $(77.2 \% ; \mathrm{n}=220)$. This difference is remarkable and highly significant $(\mathrm{p}<0.0001)$. What seems to be emerging in English conditionals is a tendency for functional complementarity, with neutrality expressed predominantly by 'if'-conditionals and non-neutrality (especially counterfactuality) overwhelmingly expressed by V1-conditionals. This confirms our suspicion that mixed V1-conditionals with 'should' and a neutrality reading contradict the tendency for V1-conditionals to specialize for non-neutrality.

With regard to German, the assumption that V1-conditionals show at least some degree of specialization for non-neutrality is confirmed: although V1conditionals show non-neutrality in German far more rarely (at 28.3\%, as shown by Figure 7) than in English, the share of non-neutrality patterns is relatively high in German, too. As with English 'if'-conditionals above, a comparison with 'wenn'-conditionals yields instructive observations. A random sample of 500 German 'wenn'-conditionals was similarly extracted from the DeReKo's Tagged-TEI-Archiv; tokens with linkage at the inferential or illocutionary levels (which amounted to 122, far less than the 215 out of 500 English 'if'conditionals but more than the 480 out of 500 German V1-conditionals) were deselected manually. The 378 remaining content-level 'wenn'-conditionals were analyzed for neutrality and non-neutrality, as shown in Figure 9.

Figure 91. Probability readings in German 'wenn'-conditionals.

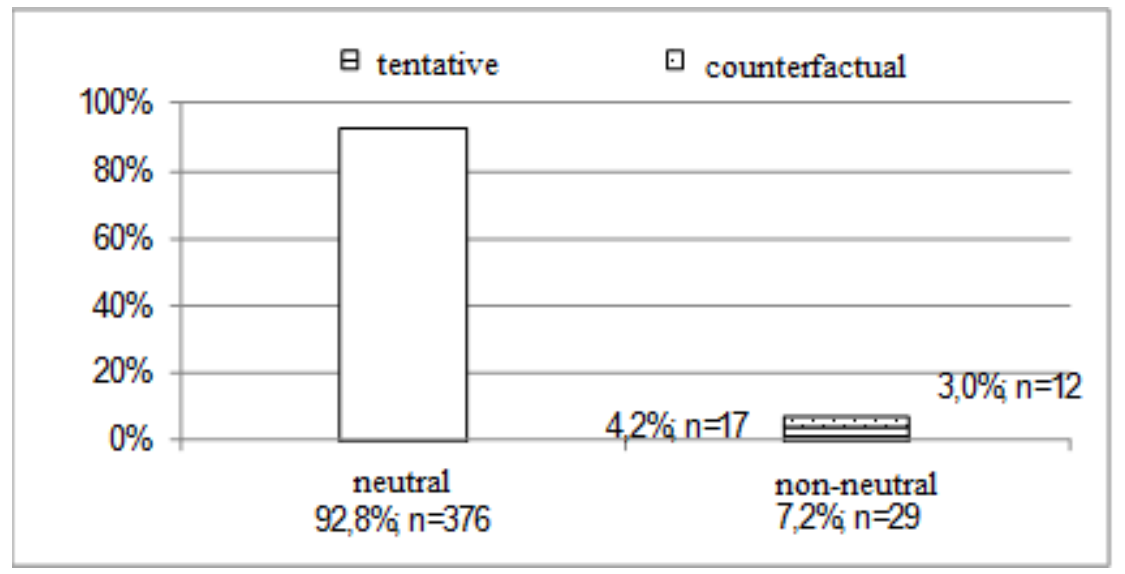


Unlike in English, V1- and 'wenn'-conditionals in German resemble each other insofar as neutrality is the most frequent reading in each language. At the same time, neutrality is more frequent in 'wenn'-conditionals $(92.8 \%)$ than in V1conditionals $(71.7 \%)$; conversely, non-neutrality is about four times as frequent in V1-conditionals (28.3\%) as in 'wenn'-conditionals (just 7.2\%); as in English, this difference is highly significant statistically (FET; $p<0.0001$ ). So even though mixed 'sollte'-conditionals clearly buck the trend in German, too, the effect is less spectacular than in English because German V1-conditionals lead less of a niche existence vis-à-vis 'wenn'-conditionals than their English V1counterparts do vis-à-vis 'if'-conditionals.

\section{Conclusions}

At the start of the present paper, we observed how the Merkel slogan (1) along with similar V1-conditionals in German seemed to accentuate the differences between V1-conditionals in German and English: in contrast to German, it is impossible to form V1-protases in English with a main verb, or indeed with any verb in the indicative, due to the exclusive use of 'should', 'had' and 'were'. Since this restriction does not seem to have applied to the same extent in the past, it has been suggested in the literature that V1-conditionals have been evolving in an asynchronous fashion in the two languages, with English leading the way down the same grammaticalization path from presumed joint origins in polar interrogatives (König 2012:8f.). While any diachronic investigation that could confirm or disconfirm this assumption on the basis of historical data had to remain outside the remit of the present paper, our initial observations did allow us to set up working hypothesis that were testable upon present-day data, focusing on Hopper's (1991) grammaticalization criteria of divergence and specialization. Divergence was defined through lexical overlap between V1protases and polar interrogatives, and specialization through functional overlap between V1-conditionals and 'if-/wenn'-conditionals as seen in the tense-moodpatterns indicating different probability readings. Our expectation was that English V1-conditionals would turn out to be highly divergent from polar interrogatives and to occupy a functional niche with respect to 'if'-conditionals, with their German counterparts showing more transitional characteristics in both respects. Telltale signs that German has been advancing down the same path as English towards more divergence and specialization, if more slowly, were of particular interest.

Our empirical investigation, based on corpus data from the BNC and DeReKo corpora, broadly confirmed these hypotheses. It also fleshed out the notion of 'functional overlap' by demonstrating a robust complementarity in English between 'if'- and V1-conditionals with respect to the expression of neutrality and non-neutrality readings and by showing that this trends coexists with an opposing tendency for 'should' (which similarly affects German 'sollte') to express neutrality in combination with present or future verb forms. The latter observation is compatible with the asynchronicity hypothesis insofar as 'should/sollte' seems to have become semantically vague, at least for some speakers, due to a loss of paradigmatic distinctness from other forms of 'shall/sollen' in conditionals. 
The main issues for future research are clearly twofold. On the one hand, there are other constructional aspects of V1-conditionals that merit investigation, such as clause order. In both German and English, V1-protases can be sentence-final as well as sentence-initial:

(69) Er wäre eingeschlafen, hätte er der Predigt noch länger zuhören müssen. (Reis and Wöllstein 2010:139)

"He would have fallen asleep had he been obliged to listen to the sermon any longer."

Interestingly, sentence-final (and indeed sentence-medial) placement of V1protases in German is more or less restricted to pattern B or (as in the example) pattern $\mathrm{C}$ verb forms, while pattern $\mathrm{A}$ forms tend to be avoided to varying degrees (Reis and Wöllstein 2010:138-140, Pittner 2011:89-82). This is indirectly confirmed by Angela Merkel herself, whose sole documented use of (1) with a sentence-final protasis involves a 'wenn'-protasis in (70) rather than the (just) conceivable V1 version in (70) ${ }^{\prime}{ }^{11}$

(70) Europa scheitert, wenn der Euro scheitert.

Europe fails if the Euro fails

(70)' ?Europa scheitert, scheitert der Euro.

Europe fails fails the Euro

The same tendency to restrict sentence-final V1-protases to pattern B and C forms seems to hold to a greater or lesser extent in other Germanic languages (Iatridou and Embick 1994:190-193). This is remarkable because even in German, V1-protases therefore tend to be more like their English counterparts, and hence less like interrogatives, if used non-initially. ${ }^{12}$

The other main issue arising from our contrastive observations concerning V1-conditionals in present-day English and German is how the present-day situation is to be interpreted diachronically: were V1-conditionals in earlier English really more like V1-conditionals in present-day German, and does their evolution show an increase of divergence from polar interrogatives and of specialization for conditionality? If so, how clear is the link (as suggested by Hawkins 1986:210-213) between these developments and the more marginal status of V1 in the English SVO environment generally? Since V1-conditionals in closely related languages like Swedish (Hilpert 2010, Auer and Lindström 2012) and anecdotally also Dutch seem to behave much more like German than English, at least in written registers, ${ }^{13}$ it is tempting to look for an explanation in the context of the divergent development of the English grammatical system at large. The stage is clearly set for a panchronic, Germanic-wide comparison in which issues of register and spoken usage should play a larger role than we have been able to achieve in the present investigation, which focused on V1conditionals in two clearly divergent languages in written usage only.

\section{References}

Auer, P. and Lindström, J. 2012. "Verb-first conditionals in German and Swedish: convergence in writing, divergence in speaking.". In Constructions: Emerging 
and Emergent, P. Auer and S. Pfänder (eds), 218-262. Berlin and Boston: de Gruyter.

Baird, W.D. and Goble, D. 1994. The Story of Oklahoma. Norman: University of Oklahoma Press.

Bhatt, R. and Pancheva, R. 2006. "Conditionals". In The Blackwell Companion to Syntax, vol. 4, M. Everaert and H. van Riensdijk (eds), 638-687. Oxford: Blackwell.

Biber, D., Johansson, S. and Leech, G. 2000. Longman Grammar of Spoken and Written English. Harlow: Longman.

Dancygier, B. 1998. Conditionals and Prediction: Time, Knowledge, and Causation in Conditional Constructions. Cambridge: Cambridge University Press.

Declerck, R. and Reed, S. 2001. Conditionals: A Comprehensive Empirical Analysis. Berlin and New York: Mouton de Gruyter.

Engel, U. 2004. Deutsche Grammatik. Neubearbeitung. München: Iudicium.

Fleischer, J. and Simon, H.J. (eds) 2013. Sprachwandelvergleich - Comparing Diachronies. Berlin and Boston: de Gruyter.

Fleischmann, K. 1973. Verbstellung und Relieftheorie. Ein Versuch zur Geschichte des deutschen Nebensatzes. München: Fink.

Haegeman, L. 2010 "The movement derivation of conditional clauses". Linguistic Inquiry 41: 595-621.

Haumann, D. 1995. "Sentential adjuncts". EESE 6/1995: 101-146. Available at http://webdoc.sub.gwdg.de/edoc/ia/eese/articles/hauman n/6_95.html\#2.1, [last accessed 14 August 2014]

Hawkins, J.A. 1986. A Comparative Typology of English and German: Unifying the Contrasts. London: Croom Helm.

Hilpert, M. 2010. "What can synchronic gradience tell us about reanalysis?". In Gradience, Gradualness and Grammaticalization, E.C. Traugott and G. Trousdale (eds), 181-201. Amsterdam and Philadelphia: Benjamins.

Hopper, P.J. 1975. The Syntax of the Simple Sentence in Proto-Germanic. The Hague and Paris: Mouton.

Hopper, P.J. 1991. "On some principles of grammaticization". In Approaches to Grammaticalization. Volume 1: Focus on Theoretical and Methodological Issues, E.C. Traugott and B. Heine (eds), 17-35. Amsterdam and Philadelphia: Benjamins.

Huddleston, R.D. and Pullum, G.K. 2002. The Cambridge Grammar of the English Language. Cambridge: Cambridge University Press.

Iatridou, S. and Embick, D. 1994. "Conditional inversion". Proceedings of the NorthEastern Linguistic Society 24: 133-147.

Imo, W. 2012. "Online changes in syntactic gestalts in spoken German". In Constructions: Emerging and Emergent, P. Auer and S. Pfänder (eds), 127-155. Berlin and Boston: de Gruyter.

Jespersen, O. 1940. A Modern English Grammar on Historical Principles. Part V. Syntax. Fourth Volume. Heidelberg: Winter.

Kim, J.-B. 2011. "Conditional inversion: a construction-based approach". Language and Information 15: 13-29.

König, E. 2012. "Comparative linguistics and language comparison". Languages in Contrast 12: 3-26.

König, E. and Gast, V. 2012. Understanding English-German Contrasts. Third edition. Berlin: Schmidt.

König, E. and van der Auwera, J. 1988. "Clause integration in German and Dutch conditionals, concessive conditionals, and concessives". In Clause Combining in Grammar and Discourse, J. Haiman and S.A. Thompson (eds), 101-133. Amsterdam and Philadelphia: Benjamins.

Leech, G. 2004. Meaning and the English Verb. Third edition. Harlow: Pearson. 
Leirbukt, O. 1997. "Über Wahrscheinlichkeitsgradierung und Illokutionen bei Konditionalgefügen". In Aspekte der Modalität im Deutschen - auch in kontrastiver Sicht, F. Debus and O. Leirbukt (eds), 77-101. Hildesheim: Olms.

Pascual, E. 2014. Fictive Interaction: The Conversation Frame in Thought, Language and Discourse. Amsterdam and Philadelphia: Benjamins.

Pittner, K. 2011. "Anmerkungen zur (Un-)Integriertheit von Konditionalsätzen mit Verberststellung". Zeitschrift für Sprachwissenschaft 30: 75-105.

Poutsma, H. 1929. A Grammar of Late Modern English. Part I: The Sentence. Second Half: The Composite Sentence. Second edition. Groningen: Noordhoff.

Quirk, R., Greenbaum, S., Leech, G. and Svartvik, J. 1985. A Comprehensive Grammar of the English Language. London: Longman.

Reis, M. and Wöllstein, A. 2010. "Zur Grammatik (vor allem) konditionaler V1-Gefüge im Deutschen”. Zeitschrift für Sprachwissenschaft 29: 111-179.

Schwenter, S.A. 1999. The Pragmatics of Conditional Marking: Implicature, Scalarity, and Exclusivity. New York and London: Garland.

Sinclair, J. (ed). 1996. Collins COBUILD English grammar. London: HarperCollins.

Sweetser, E. 1990. From Etymology to Pragmatics: Metaphorical and Cultural Aspects of Semantic Structure. Cambridge: C.U.P.

Szczepaniak, R. 2013. "Satztyp und Sprachwandel”. In: Satzypen des Deutschen, J. Meibauer, M. Steinbach and H. Altmann (eds), 738-763. Berlin and Boston: de Gruyter.

Traugott, E.C. 1985. “Conditional markers". In Iconicity in Syntax, J. Haiman (ed), 289-307. Amsterdam and Philadelphia: Benjamins.

Van den Nest, D. 2010a. Emergenz und Grammatikalisierung von V1-Konditionalen. Ein Rekonstruktionsversuch am Beispiel des Deutschen und Englischen. Ph.D. Diss. Ghent University.

Van den Nest, D. 2010b. "Should conditionals be emergent...: Asyndetic subordination in English and German as a challenge to grammaticalization research". In Formal Evidence in Grammaticalization Research, An Van linden, J.-C. Verstraete and K. Davidse (eds), 93-136. Amsterdam and Philadelphia: Benjamins.

van der Auwera, J. 1997. "Pragmatics in the last quarter century: the case of conditional perfection". Journal of Pragmatics 27: 261-274.

\section{Notes}

1 See https://www.youtube.com/watch?v=C3zMhindIXw (last accessed 31-08-2014) for four instances of (1) in speeches and interviews by Merkel, with some variation in detail.

${ }^{2}$ A third, more marginal version has 'so' and 'will': "If the Euro fails, so will Europe."

${ }^{3}$ YCOE $=$ York-Toronto-Helsinki Parsed Corpus of Old English Prose, accessed through http://www-users.york.ac.uk/ lang22/YcoeHome1.htm; PPCME2 = Penn-Helsinki Parsed Corpus of Middle English, second edition, accessed through http://www.ling.upenn.edu/histcorpora/.

${ }^{4}$ Similar assumptions are made independently in contrastive studies by Hilpert (2010) and Auer and Lindström (2012) of V1-conditionals in present-day German and Swedish. It would be tempting for us to consider both studies in more detail (as suggested by an anonymous reviewer, who brought up Auer and Lindström 2012), not least because they discuss important issues of register and spoken usage; cf. section 4 for perspectives for future investigations which should take account of these parameters. As far as the present study is concerned, lack of space obliges us to stick to our own, slightly different research agenda.

${ }^{5}$ The BNC was accessed via Sara (now superseded by Xiara, http://www.natcorp.ox.ac.uk/tools/ index.xml) and BNCWeb (http://bncweb.lancs.ac.uk), the DeReKo through the Institut für Deutsche Sprache (https://cosmas2..ids-mannheim.de/cosmas2-web).

${ }^{6}$ Note that this is distinct from accepting the interrogative origin of V1-conditionals as a fact (as König 2012, Hilpert 2010, and Auer and Lindström 2012 seem to do). Good reasons for not 
choosing between interrogatives and declaratives as the historical 'source' of V1-conditionals are implicitly suggested by Fleischmann (1973: 228): V1-order must at some stage have been reanalysed as a subordination marker, and since V1 routinely occurred in both interrogatives and declaratives in ancient Germanic (cf. also Szczepaniak 2013), the question whether V1-marking arose from one particular clause type as opposed to the other implies a false choice. Unfortunately, since we are exclusively concerned with the synchronic perspective in the present paper, this is yet another intriguing issue that must be left for another occasion.

${ }^{7}$ Note that the standard reference work on German-English contrasts, König and Gast (2012), only touches upon V1-conditionals superficially in the context of subject-verb inversion (ibd.: 198f.). A slightly more elaborate comparison can be found in Hawkins (1986: 195-213), but his discussion is informed by a different research agenda and outdated both theoretically and methodologically.

8 The phrase 'were it not for' is not attested in interrogatives.

9 Searching for V1-conditionals in German corpora is not straightforward, given that German V1-conditionals are not lexically marked. This is why the Tagged-TEI-Archiv was used instead of the full DeReKo, which made it possible to find V1-protases (using the Cosmas II search engine) through the appropriate tags in conjunction with punctuation marks etc. False positives still had to be manually weeded out on a large scale.

${ }^{10}$ Minority possibilities are the future tense in the apodosis and the present perfect in the protasis. They are attested in our corpus (if rarely) and will be illustrated below.

${ }^{11} \mathrm{Cf}$. the video sequence cited in footnote 1 .

12 The question arises whether this observation can be linked to the apparent tendency for V1clauses (observed by Auer and Lindström 2012: 250-258 in spoken German) to project for independent illocutionary force. Speakers conceivably tend to avoid sentence-final V1-protases unless the mood is non-neutral and therefore distinct from interrogatives (ibd.). The problem with this account is that it is partly ad-hoc (whether it holds for Swedish to the same extent remains unclear, ibd.) and that it is contradicted by studies of constructional projection which explicitly state that "interactants can live with ambiguity", that fuzziness is ubiquitous in language anyway, and that linguists should beware of constructing distinctions that are irrelevant in conversational practice (Imo 2012: 149f. with further references). Future research should investigate whether V1-constructions somehow have a special status with regard to projectional ambiguity or whether an alternative account can be found (cf. Reis and Wöllstein 2010: 138-140 for an argument based on processing considerations).

${ }^{13}$ According to Auer and Lindström (2012: 258), V1-conditionals in written German are more like V1-conditionals in English and V1-conditionals in spoken German are more like V1conditionals in Swedish. However, many of their generalizations concerning the usage patterns and functions of V1-conditionals in either written and spoken language are (understandably) based on restricted data and should be checked against a larger, more diversified set. 